\title{
Who wants a referendum on EU membership? Exploring public attitudes in six Member States
}

\author{
Jan Eichhorn ${ }^{\mathrm{a}}$, Daniel Kenealy ${ }^{\mathrm{a}}$ and Christine Hübner ${ }^{\mathrm{b}}$ \\ aSocial Policy (School of Social and Political Science), University of Edinburgh, Edinburgh, UK; 'bShool of \\ Social Sciences, Nottingham Trent University, Nottingham, UK
}

\begin{abstract}
Using data from a survey conducted in six EU Member States, we explore what drives citizen demand for referendums on EU membership. We examine whether or not similar drivers and mechanisms can be found across the countries surveyed. We consider what are traditionally understood to be the drivers of euroscepticism, exploring whether those same drivers help to explain demand for referendums on EU membership. Our most important finding is that citizens' attitudes to EU referendums are not driven, or explained, by a single issue, or by uniform mechanisms cross-nationally. Although we find that trust in EU institutions is a significant predictor of referendum demand, the impact of other factors considered varies substantially across the six countries.
\end{abstract}

\section{KEYWORDS}

Referendums; euroscepticism; European integration; public attitudes; Brexit

\section{Introduction}

In this article, we investigate what drives public demand for national referendums about a country's membership of the EU. Our analysis is based on data collected in a survey administered in six EU Member States - France, Germany, Ireland, Poland, Spain, and Sweden - leading up to the UK's referendum on its membership of the EU in June 2016. Survey respondents were answering at a time when a referendum on EU membership was on the horizon, and no longer a purely hypothetical situation. There was considerable speculation in the media around the time of the UK's referendum about the potential for similar referendums elsewhere (Bagehot 2016; Henley 2016; Oliver 2016a). Despite such speculation there was little analysis then, or since, of the possible drivers of demand for EU membership referendums outside of the UK (for a recent exception, see De Vries 2017).

There is evidence of a close relationship between public attitudes to the EU and popular support for EU-related referendums (Schuck and de Vreese 2015). On one hand, dissatisfaction with the EU has previously been found to be a key driver of popular support for EU-related referendums (Rose and Borz 2013). On the other hand, referendums are potentially fuelling eurosceptic attitudes. As Brack and Startin $(2015,240)$ observe, 'EU-related referendums have become a key feature of this mainstreaming [of euroscepticism] process and have served to underline the power of EU citizens to put the brakes on, and potentially derail, the European integration process'. 
In the lead up to the UK's referendum the possibility of other countries demanding their own referendums was often spoken of in a singular way, as if the factors that might drive the demand for further referendums were uniform across the EU. In this article we explore whether this is the case, or whether there are differences across the six countries surveyed. We contribute to debates about EU referendum demand and attitudes to the EU more broadly by investigating the linkages between referendum demand, public attitudes towards integration and: institutional trust; identity; left-right positioning; concerns about immigration; and concerns about the economy. Our findings highlight important suggestions for further research on public attitudes towards EU membership referendums.

The next section situates the research within the literature on the drivers of public demand for EU referendums, and on public attitudes to the EU, allowing us to formulate hypotheses. We then explain our methods and data collection before presenting the results of our regression analyses. Finally, we offer a discussion of the results in line with our hypotheses. We close by offering some thoughts on future research possibilities.

\section{Literature review}

There has been a growing number of EU-related referendums since the 1970s (Hobolt 2009), although only two have involved the consideration of membership by an existing Member State. ${ }^{1}$ Referendums are popular with publics in general. They are easily justified as additional opportunity for citizens to be involved in political decision making (Bowler and Donovan 1998; Dalton, Burklin, and Drummond 2001). While politicians and EU officials traditionally oppose EU referendums, public demand for referendums about EU issues is high. The European Election Study shows that in 2009, for example, 63 per cent of Europeans were positive about EU referendums overall. Yet, support for referendums varied substantially across countries, with almost 88 per cent in favour of referendums on EU issues in Ireland and less than 45 per cent in Sweden (van Egmond et al. 2013). Given the precedent of the UK's EU referendum, what drives demands for EU referendums in different countries? And how similar are these drivers across countries?

\section{Drivers of EU membership referendum demand}

Two possible drivers of referendum demand in general have been identified in the existing literature: cognitive mobilisation and political disaffection. The cognitive mobilisation approach posits that with rising levels of education and political knowledge, citizens more often demand to have their voice heard, for example, in referendums (Dalton 1984; Inglehart 1970). Hence, it is those citizens who are better educated, have a better grasp of, and are consequently more interested in, politics that are driving demand for referendums. For them referendums present an additional opportunity for political expression (Schuck and de Vreese 2015). In a six-country study, including Sweden and Finland, Donovan and Karp (2006) find that it is younger citizens especially, and those most interested in politics, who are in favour of holding referendums. Following this, we would expect that: 
H1: Citizens who are younger, better educated, and more knowledgeable about the EU are more likely to demand EU referendums.

In a study including 27 EU member states Rose and Borz (2013) find support for the cognitive mobilisation hypothesis. However, they conclude that, in the specific context of demand for EU-related referendums, dissatisfaction with the performance of the EU is a much stronger predictor of demand. The political disaffection school posits that EUrelated referendums are primarily demanded by those citizens who are most sceptical of the EU or politics in general. Rose and Borz $(2013,625)$ observe, 'the less satisfied individuals are with the performance of the EU [...], the more likely they are to favour EU referendums'. Schuck and de Vreese (2015) show for 21 EU countries that - independent of the level of satisfaction with the EU - referendums are more likely to be demanded by citizens who lack confidence in established political actors, perceive themselves to be on the periphery of political processes, and sometimes display cynical attitudes towards politics. For these citizens, referendums provide an alternative means of expressing opinions that otherwise are felt to go unheard.

Though not specific to EU referendum demand, it is further suggested that political disaffection from the domestic level might be transferred to the EU level when it comes to EU attitudes in general, commonly termed the congruence hypothesis (Rohrschneider 2002). In line with the political disaffection hypothesis, this could also lead people who lack trust in national institutions to demand a referendum on EU integration. In contrast to that, other research argues that a low opinion of national institutions, coupled with a high opinion of EU institutions, would generate support for the EU, commonly termed the compensation hypothesis (Sanchez-Cuenca 2000; Kritzinger 2003). Whether congruent or compensating, according to McLaren $(2007,236)$ ultimately, 'it is unclear as to how attitudes to institutions ought to affect attitudes to European integration'. From this discussion of political disaffection we can derive the following:

H2a: Citizens who lack confidence in national and European political actors are more likely to demand EU referendums.

$H 2 b$ : Citizens who have high confidence in national political actors, but lack confidence in EU institutions are more likely to demand EU referendums.

\section{Euroscepticism and EU referendums}

Given that evidence suggests a relationship between disliking the EU and demanding EU-related referendums, we might expect the known drivers of euroscepticism to play a role in driving EU-referendum demand. The concept of euroscepticism has been nuanced over recent years. For example, Stöckel $(2013,40)$ identified differing causal logics of ambivalence and indifference towards the EU, chiming with 'a growing body of literature that casts doubt on the assumption that citizens view political issues and objects in an exclusively positive or negative way' (see also De Vries and Steenbergen 2013). In a similar vein, Boomgaarden et al. (2011) argue that EU attitudes ought to be studied in a multidimensional way, with each dimension being linked distinctively to various explanatory factors. Furthermore, in the context of national referendums, votes 
cast against EU endorsed proposals do not always reflect general dissatisfaction with the Union (Hobolt and Brouard 2011). Thus, an individuals' vote choice in a hypothetical referendum cannot by itself capture the complexities of their attitudes towards the EU. Whilst it is important to note these nuances, in this article we are interested in using the existing literature on euroscepticism to identify potential drivers of demand for EU membership referendums, not to further nuance the concept of euroscepticism itself.

There is an extensive literature on the drivers of euroscepticism, focusing on utilitarian or economic, cue taking, and identity-based explanations (see Hobolt 2012; Hobolt and De Vries 2016). Perceived economic prospects and immigration sentiments play a role when citizens evaluate EU integration (see De Vreese and Boomgaarden 2005; Rohrschneider and Whitefield 2006; Loveless 2010). In particular, higher levels of immigration as a result of EU integration can be perceived either as threat to the economy or as threat to cultural identity. Consequently, De Vreese and Boomgaarden (2005, 70-71) find that anti-immigration sentiments - along with economic evaluations - are one of the strongest predictors of attitudes towards EU integration. Further, many studies have argued that since people rarely have direct experiences with the EU, they use proxies or cues from political parties or elites to make an evaluation instead (Hooghe and Marks 2005). Especially extreme parties on the left-right continuum are found to have an impact on the prevalence of eurosceptic attitudes among their followers (De Vries and Edwards 2009).

Lastly, while generally not included in theories about demand for EU-related referendums, research has shown that differing degrees of national and European identification are key drivers of citizens' perceptions of European integration (Hooghe and Marks 2004, 2005; McLaren 2004, 2007). A stronger identification with the EU can lead people to be more loyal to, and more supportive of their country's membership in, the EU (Carey 2002; Citrin and Sides 2004). National and European identities are not necessarily mutually exclusive and individuals can draw on multiple identities that accumulate, are embedded in - or even reinforce - each other (Diez Medrano and Gutiérrez 2001). A strong national identity can, thus, reinforce EU identification. A weaker national identity, in contrast, would be expected to be related to eurosceptic attitudes and to EU referendum demand. From this literature we derive the following hypotheses reflecting discussions about drivers of euroscepticism:

H3a: Weak national or EU identification is associated with people to be more likely to demand EU referendums.

H3b: Anti-immigration attitudes are associated with people to be more likely to demand EU referendums.

H3c: Support for extreme left/right parties is associated with people to be more likely to demand EU referendums.

\section{Similarities or differences across countries}

Although many studies of euroscepticism report robust effects across countries (e.g. Leconte 2015, 254), others argue that the national context can be expected to be 'sticky' when it comes to determining drivers of euroscepticism (Hooghe and Marks 2004; Diez 
Medrano 2003). Neither Rose and Borz (2013) nor Schuck and de Vreese (2015) report details about country differences in their results but they do emphasise that the national context also impacts referendum demand. Numerous factors at the national level - such as perceptions of corruption, the number of and experience of referendums historically, the national economic context, the quality of national political institutions - may play a role in determining demand for referendums (see De Vries 2017; Emanuele, Maggini, and Marino 2016; Rose and Borz 2013; Schuck and de Vreese 2015). To investigate whether we find uniform mechanisms at work across our countries or not, we have formulated a hypothesis that allows us to address this question empirically:

H4: Across different EU member states, similar factors account for EU referendum demand.

\section{Referendum demand and referendum choices}

Referendums require voters to make explicit choices. Latent evaluations - such as trust and distrust in EU institutions or affection and disaffection with a European identity - may directly affect the desirability of a public vote (Rose and Borz 2013, 627; Schuck and de Vreese 2015, 155). However, those factors may also manifest in an explicit desire for membership of, or leaving, the EU. We may therefore expect that a strong predictor of referendum demand would be the desire to remain in or leave the EU. In this context we would expect those who would want to change the status quo and see their country leave to be more supportive of a referendum that may enable them to do so. Additionally, we would also expect to see an indirect effect: as the desire to remain in or leave the EU is likely to be influenced by many of the factors discussed above, we would expect the strength of the relationship between these factors and demand for a referendum to reduce, when taking into account how people would vote in such a referendum. This leads us to formulate two further hypotheses:

H5a: Citizens who would vote to leave the EU in a hypothetical referendum in their country are more likely to support holding such a referendum.

H5b: When controlling for how citizens would vote in a hypothetical referendum on their country's EU membership the strength of the relationships between other factors and the demand for a referendum is reduced.

\section{Data and methods}

Our analyses are based on a survey of 8002 respondents in Germany, France, Poland, Spain, Ireland, and Sweden conducted between 22 January and 8 February 2016. Respondents were invited to take part in a 20-minute survey involving 50 questions. The survey was carried out online to enable us to achieve wide and representative coverage in six EU countries within a short time before the UK's referendum in June 2016. 1500 respondents were interviewed in Germany, France, Poland and Spain and a further 1000 in Ireland and 1002 in Sweden. All questions were administered in the respective national language. In order to reach a nationally representative sample, stratification variables for age, sex, regions (with monitoring of sub-national geography), 
educational attainment, and income were applied. Where possible, cross-quotas were used to enhance the degree of representativeness, which extended the duration of the fieldwork, but ensured smaller degrees of deviation. While most stratification targets were reached by natural fallout, respondents with higher education degrees were slightly overrepresented - as is common in such surveys - and had to be screened accordingly after initial targets were reached. Remaining minor deviations from population profiles were corrected for by applying weights. ${ }^{3}$ Sensitivity checks reveal no significant impact of weighting on substantive results. ${ }^{4}$ It would have been desirable to have data for more countries to conduct multilevel analyses to assess potential country-level influences on the results systematically. Unfortunately, for that point in time no existing survey for that with the required mix of dependent and independent variables was available that would have allowed this study to be carried out. Therefore, we have to rely on the data for these six countries.

\section{Descriptive results}

When examining the question on public demand for EU membership referendums, we find that demand is not at similar levels in the six countries included in this study. In France a majority of people would like to see a referendum on EU membership (53 per cent) and in Sweden, Germany, and Spain there are more respondents in favour of holding a similar referendum than are opposed to it (Table 1). In Poland and Ireland the opposite is true, with more people not wanting a referendum than wanting one.

The data further indicate that the relationship between euroscepticism and demand for EU referendums may be more complex than the literature suggests. We cannot simply assume that higher percentages wanting a referendum equate to a more eurosceptic public. Indeed, support for EU referendums is generally high and - albeit not quite as high - roughly in line with data from the 2009 European Election Study. Majorities of people in most countries, however, would vote for their country to remain in the EU if such referendums were held. Only in France and Sweden do we find substantial minorities who would vote for their country to leave the EU (33 per cent and 37 per cent respectively). Combining referendum demand and voting intentions, we find that although the overwhelming majority of those who want their country to leave the EU would also like to have a referendum on membership, substantial proportions of those who want their country to remain in the EU also favour such a referendum. Up to 40 per cent of those who favour a referendum would nevertheless vote for their country to remain in the EU. This hints at there being other drivers of referendum demand beyond hard euroscepticism.

Table 1. Desirability of own referendum and voting intention in such a referendum by country.

\begin{tabular}{lccccccc}
\hline & \multicolumn{2}{c}{ Wanting an own referendum (\%) } & & \multicolumn{3}{c}{ Vote intention in hypothetical referendum (\%) } \\
\cline { 2 - 3 } & Yes & No & Don't know & & Yes & No & Don't know \\
\hline Germany & 44.7 & 40.1 & 15.2 & & 59.6 & 26.8 & 13.5 \\
France & 53.3 & 28.7 & 18.0 & & 45.2 & 33.2 & 21.5 \\
Poland & 39.0 & 45.1 & 15.9 & & 65.7 & 20.1 & 14.2 \\
Spain & 47.3 & 39.3 & 13.3 & & 67.8 & 18.3 & 13.9 \\
Ireland & 37.7 & 48.6 & 13.7 & & 69.1 & 18.0 & 20.6 \\
Sweden & 48.8 & 33.1 & 18.1 & & 42.4 & 37.1 & \\
\hline
\end{tabular}

N for Germany, France, Poland, Spain: 1500, N for Ireland: 1000, N for Sweden: 1002 


\section{Analytical approach}

We use binary logistic regression models to assess what drives demand for referendums on EU membership and who is most likely to demand one. We model individual-level EU membership referendum demand using several independent variables chosen to represent the potential factors stated in our hypotheses. To explore whether predictors are uniform across the six countries, or whether there are differences across countries, we calculate an overall model and individual models per country. We coded the response options to the question on membership referendum demand to estimate the effect for wanting to hold such a referendum. We do not include respondents who answered 'Don't know'.

We include a range of socio-demographic controls - sex, age, and educational attainment - according to hypothesis 1 . We then also include a measure of knowledge about the EU. For this purpose we asked six questions with varying degrees of difficulty about different aspects of EU structures and procedures. People had to assess whether statements were true or false and we recorded the number of correct answers (0 to 6). ${ }^{6}$ To assess our second set of hypotheses on compensation and congruence we include trust in both national and supranational institutions, measured by trust in the national parliament of the respective country as well as the European Parliament.

To then engage with our third set of hypotheses on drivers of euroscepticism, we gauge the impact of identity, by asking respondents to place themselves on 7-point scales of national and European identity. From this we construct one predictor, such that the two dimensions are not independent of each other. We do this because there may be a tradeoff between national and European identity (Kriesi et al. 2006), or the two may reinforce each other (Hooghe and Marks 2005). We distinguish different types of identity by splitting respondents into the following mutually exclusive and exhaustive groups: those who marked themselves high on European identity (scores 5-7) but low on national identity (scores 1-4) as emphasising an 'exclusive European identity'; those marked high on national identity (scores 5-7) but low on European identity (scores 1-4) as emphasising 'exclusive national identity'; those marked low (scores 1-4) on both dimensions as 'neither identity'; those marked as relatively strong on both (scores 5-7, but at least one below 6 ) as emphasising 'both identities'; and those marked as high (score 6-7) on both dimensions as emphasising 'both identities strongly'. Furthermore, we then include two questions for the analysis of attitudes toward immigration: whether respondents think immigration should be reduced and what impact immigration had on the economy. This allows us to distinguish between economic and non-economic perceptions of immigration. Finally, we include a measure of self-identified location on the left-right spectrum, where we distinguish those 'far left' (scores 1-3), from those 'centre-left' (scores 4-5), 'centre-right' (scores 6-7), and 'far-right' (scores 8-10).

We estimate our regressions overall with country dummy variables first and then for each country separately to explore how similar the drivers are across countries. We first estimate models with socio-demographic independent variables only (sex, age and educational attainment - Table 2) and then include further independent variables to assess whether these impact the results (Table 3 ). We then repeat the analyses of all full models, but include an additional independent variable that measures how respondents would vote if faced with a referendum on EU membership in their own country (Table 4). 
The variable distinguishes those who would vote to remain from those who would vote to leave. Doing this allows us not only to analyse the direct effect of this variable, but also to check whether the relationships identified for other variables are robust to this control.

With data from six countries it was not possible to conduct multilevel models to account for systematic country-level variation. However, a breakdown of variance components in the dependent variable shows that 98 per cent of the variation is within countries and between individuals; only 2 per cent of variation can be attributed to the country-level. This suggests that country-level clustering effects are of little concern

\section{Results}

The only consistent predictor of EU membership referendum demand across the six countries is trust in the European Parliament. While we find other factors - such as age, education, identity or attitudes to immigration - to be significant predictors of EU referendum demand in some countries, in other countries these factors are insignificant or even impact our dependent variables in different directions.

\section{No consistent support for cognitive mobilization hypothesis}

Socio-demographic differences, education and EU-specific knowledge do not consistently impact our dependent variable. Contrary to theories on cognitive mobilization (hypothesis 1), the explanatory power of age, educational attainment and knowledge on referendum demand in our models is different across countries and limited overall. The sociodemographic profiles of proponents and opponents of referendums differ substantially across the six countries (Table 2). For example, while there is a strong effect of age in Poland, with those aged 55 and above significantly less likely to want a referendum compared to those under 35 , there are no - or even opposite - effects of age in other countries. Contrary to the cognitive mobilisation hypothesis, we find those with higher education degrees to be less likely to support a hypothetical EU-referendum , but this effect is not equally strong across countries. Similarly, EU-specific knowledge plays little to no role in most countries (Table 3). Only in France and (marginally) in Ireland are those who have more knowledge about the EU significantly less likely to want a referendum. What is more, many of these differences do not remain robust when taking into account attitudinal variables such as trust in institutions and known drivers of euroscepticism. This suggests that socio-demographics and knowledge are not consistent and important drivers of referendum demand.

\section{Trust in institutions only consistent at the EU-level}

Trust in the European Parliament is a consistent and significant predictor of demand for EU-membership referendums. In all six countries greater levels of trust in the European Parliament are associated with lower demand for a referendum on EU membership. This finding supports hypotheses about the impact of political disaffection, specifically at the EU level. Trust in national parliaments, however, is not a consistent predictor across countries. In Poland and Sweden (and marginally in France) respondents who have greater levels of trust in their national parliaments are significantly more likely to want a referendum. This indicates that the compensation mechanism may apply in some 


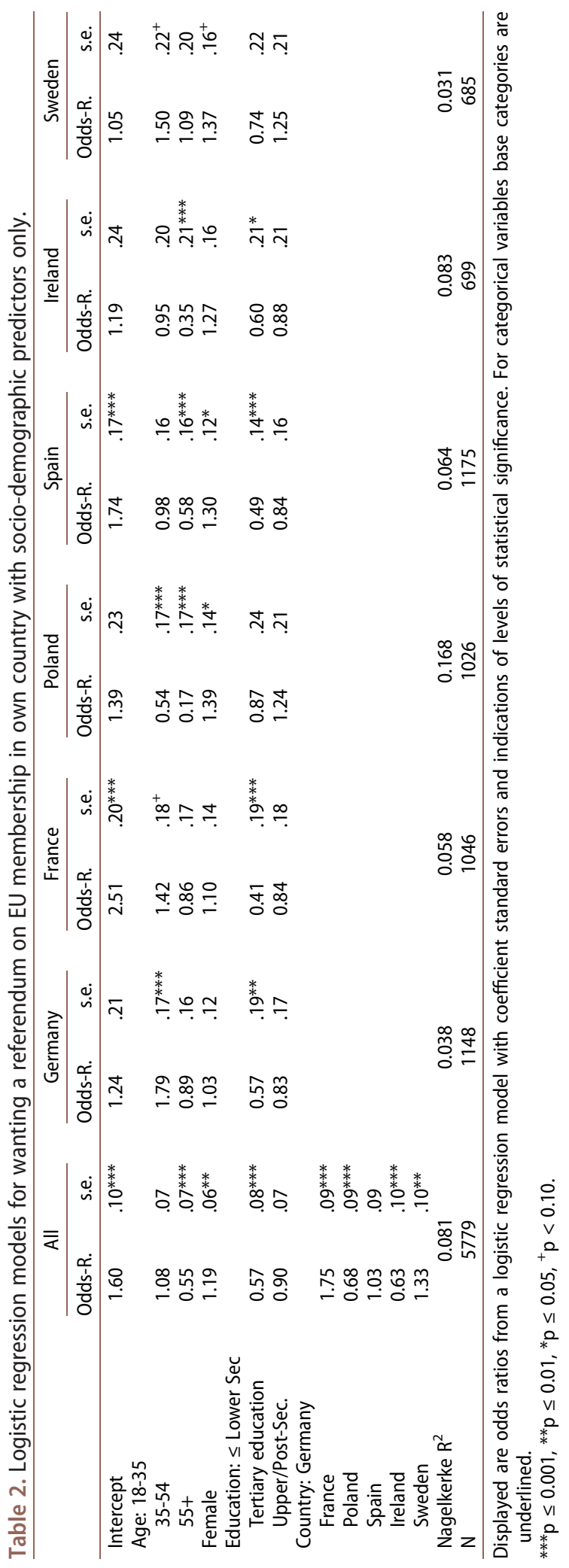




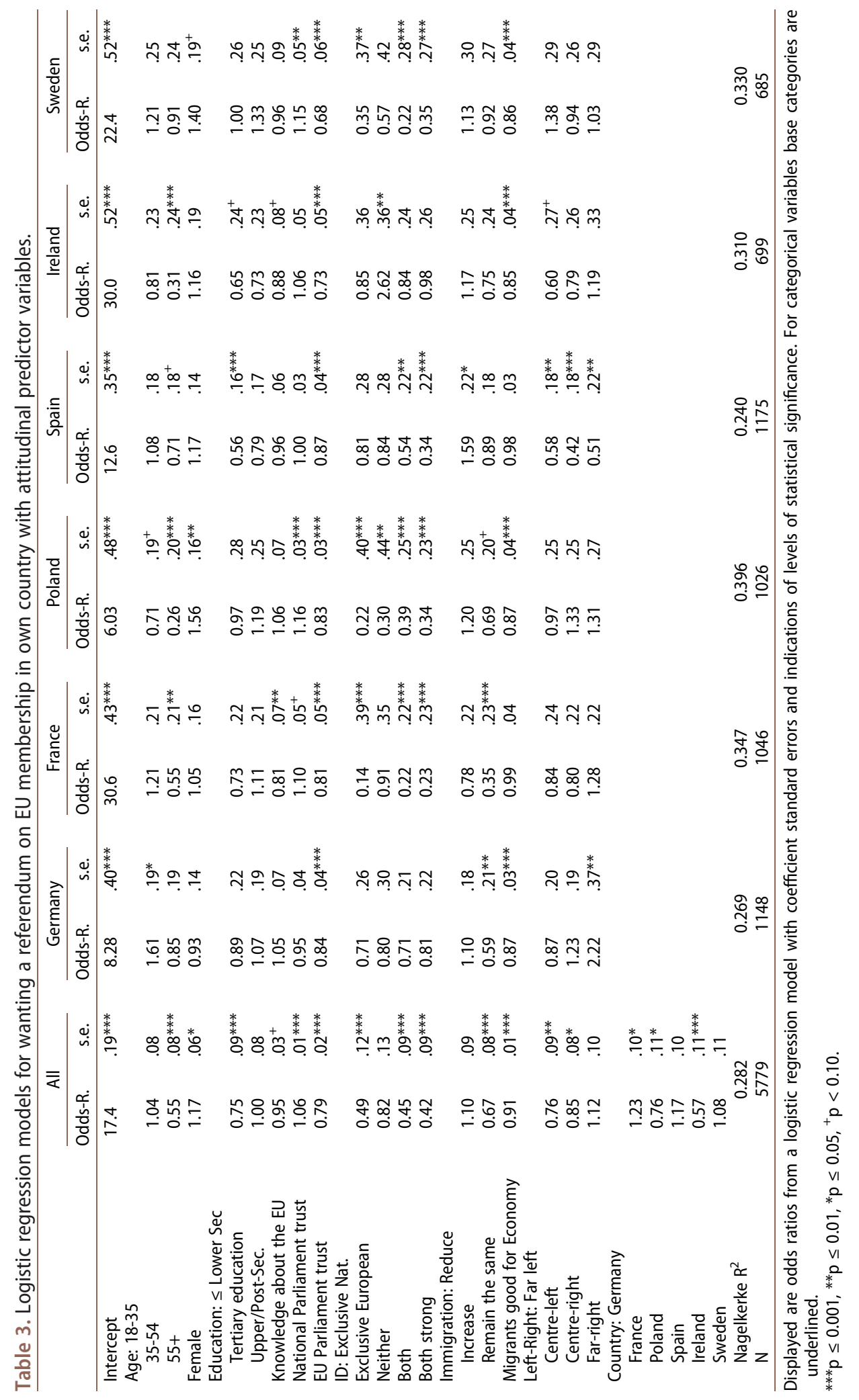




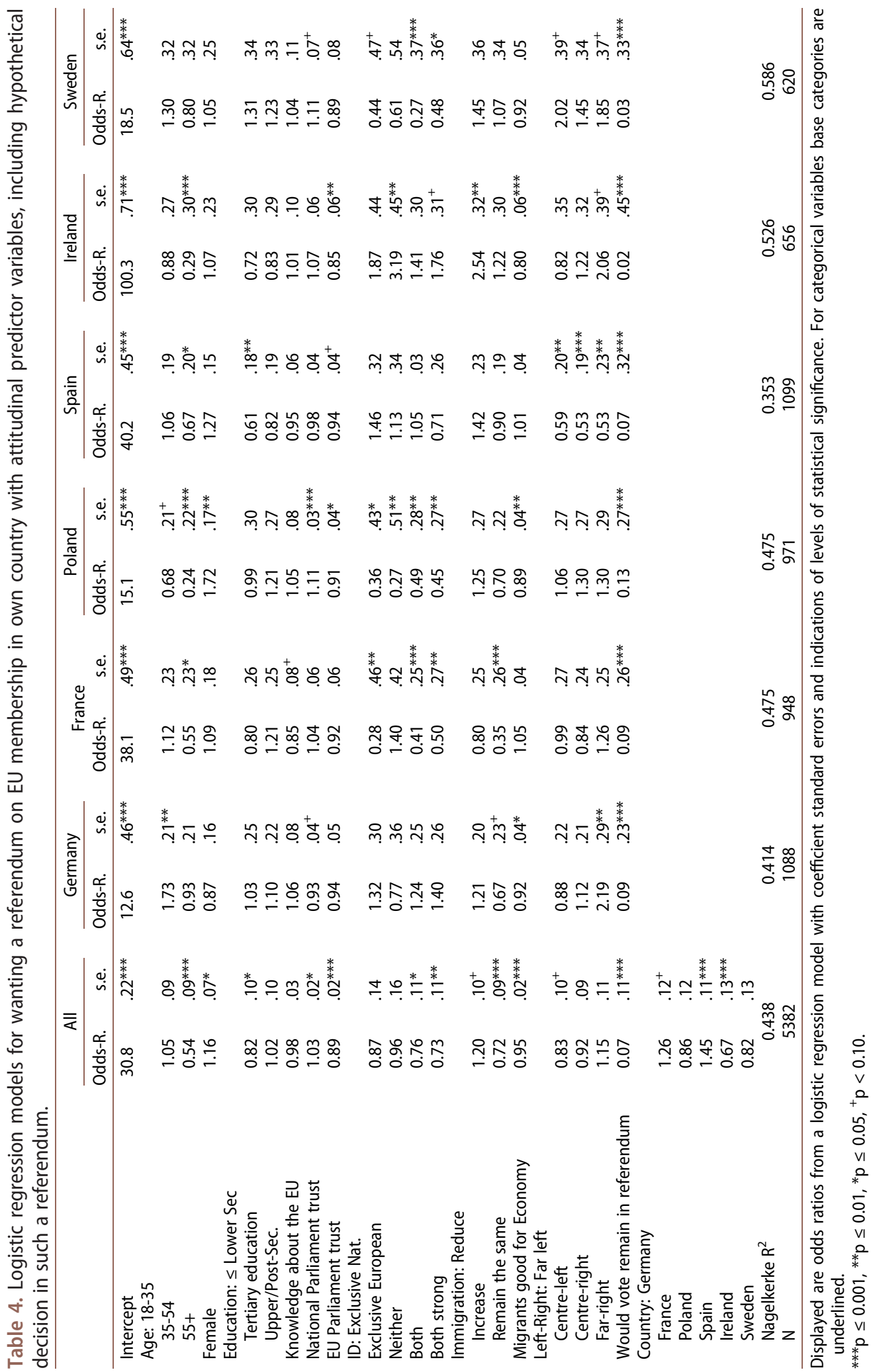


countries (hypothesis 2b). Citizens who trust their own national parliament are not supportive of EU integration and may demand a referendum, so that they can vote for their country to leave the EU. We cannot state the same for Germany, Spain and Ireland, however, where trust in national parliaments has no effect. We find no support for the congruence hypothesis (hypothesis 2b). Overall, the size of the effect of trust in the European Parliament is larger than that of trust in national parliaments.

\section{Known drivers of euroscepticism with limited impact}

Similar to trust in the European parliament we also find that identity is an interesting factor impacting EU referendum demand. Across the six countries those who identify as solely national are more likely to demand a referendum on their country's EU membership. This lends some support to hypotheses about the impact of euroscepticism, in that those citizens who do not subscribe to any form of European identity are most likely to demand a referendum and want to leave the EU (hypothesis 3a). However, the number of people who identify as solely national in their identity differs across countries. As little as 18 per cent of respondents in Spain, and as much as 38 per cent in Ireland and France, think of themselves as solely Spanish, Irish or French.

However, while strong in most countries, the effect of national identification is not significant in Germany (even though around 20 per cent of respondents identify as solely German). Furthermore, the expected opposite effect is not consistently true. Those who strongly identify with the EU, either alone or in addition to a strong national identity, are not always opposed to EU referendums. Other types of identity seem to have different effects on referendum demand across the six countries. For example, in Spain those who emphasise both identities, but not those with an exclusive European identity, are significantly less likely to want a referendum.

The impact of evaluations of immigration and the economy differs substantially across the six countries (hypothesis $3 b$ ). In some cases, such as Sweden and Germany, the perception of immigration seems to be predominantly based on economic utility: those who think immigration has positive effects on the economy are less likely to want to hold a vote on EU membership. On the contrary, both attitudinal evaluations of immigration and the economic-utility argument seem to matter in France: only those who think that immigration should remain as it is are less likely to want a referendum. In contrast to theories about party cues, left-right attitudes are of only limited relevance in our models (hypothesis 3c). Only in Germany and Spain do extreme party cues play a role. While in Germany those identifying with the far right are significantly more likely to demand an EU referendum (but not to vote to leave in such a referendum), in Spain it is the supporters of the far left who demand their own EU referendum. Overall, drivers of euroscepticism do not appear to provide a consistent profile of referendum favouring attitudes.

\section{The stickiness of the national context}

We find significant differences between the six countries in relation to factors associated with demand for a EU membership referendum (hypothesis 4). In other words, even when we account for consistent predictors such as trust in EU institutions, the profiles of proponents and opponents of referendums still differ substantially across the six 
countries. This is indicated by dummy predictors for country effects, some of which remain significant throughout the analysis. In contrast to our fourth hypothesis, these results suggest that there are no consistent and exhaustive explanations of EU referendum demand across the six countries. Irish respondents, for example, remain significantly less likely to support a referendum than respondents in other countries when controlling for all other factors. This suggests that country differences in referendum demand can only in part be explained by particular attitudes towards immigration, trust in institutions and forms of identity.

\section{Referendum demand and referendum choice}

As we expected, in all six countries respondents who would vote to remain in the EU in a hypothetical referendum are significantly less likely to want such a referendum on EU membership (hypothesis 5a). Including the respondents' vote intention in a hypothetical referendum as a control in models of referendum demand has an effect on the previously identified relationships (hypothesis $5 b$ ) reducing most of them in size. However, the impact is limited and especially results with substantive effect sizes remain statistically significant. This suggests that many of the indicators examined are independently related to both referendum demand and vote intention in a hypothetical referendum on EU membership. Most associations between socio-demographic factors and referendum demand are robust overall, except for the tertiary education effect in Ireland, which is rendered statistically insignificant after adding the control. The weak relationships between EU knowledge and referendum demand in Germany and Ireland are also rendered insignificant, further supporting the impression that knowledge about the functioning of the EU has little to do with demand for referendums overall.

Perhaps unsurprisingly we see the greatest amount of change in relation to trust in EU institutions. In three countries (Germany, France and Sweden) the previously identified negative relationship between greater trust in the EU Parliament and demand for a referendum is rendered insignificant when taking into account whether people intend to vote for their country to remain in the EU. However, in Poland, Spain and Ireland the relationship remains significant - although it reduces in strength - suggesting that in models of referendum demand the vote intention is not simply synonymous with levels of trust in the EU Parliament.

Overall, the relationship between national and EU identification and membership referendum demand remains the same after introducing the control for vote intentions in a hypothetical referendum, except for Spain, where it becomes insignificant. This suggests that the association between identity and referendum demand is not a direct effect in Spain, but is rather indirectly moderated through views on EU membership. In Poland, Spain and Sweden some of the evaluations of migration, earlier identified as related to referendum demand, are rendered insignificant when taking into account hypothetical vote choice. However, in Germany and Ireland we now find that people who want immigration to be reduced are more likely to want a referendum. These inconsistent findings suggest that the role of immigration in people's views on referendum demand and membership more generally is contingent on country context. It would require detailed examinations within the context of each country to appraise this comprehensively. 
With regards to left-right orientations, most effects are robust. There are minor differences between the models with some effects (but not all) becoming insignificant in Germany and Ireland. However, for Ireland and Sweden we find marginally significant effects after taking into account voting intentions in a hypothetical referendum. Overall, we cannot identify a consistent impact of the control.

\section{Discussion}

Our results offer little support for notions that there was widespread demand for EU membership referendums in the lead up to the UK's June 2016 vote, and certainly not demand motivated by similar factors across the EU. Based on previous multi-country studies on referendum demand and EU attitudes and the individual-level explanations they employ, we expected to at least find similar mechanisms driving referendum demand in different countries. Yet we find that the profiles of proponents and opponents of referendums in the six countries differ substantially, as do the levels of support. Not only do different factors play a role in determining individuals' preference for referendums, but what is even more notable is that the same mechanisms, for example age or left-right attitudes, operate in different directions in our countryspecific models. This leads us to conclude that simple and uniform assumptions about why people might demand referendums about their country's EU membership seem insufficient.

Instead, our findings are more in line with previous research that stated how important the national context is when it comes to interpreting citizens' attitudes towards EU referendums and European integration generally (Diez Medrano 2003; Rose and Borz 2013). There are many country-specific factors that can be expected to impact how publics in different countries evaluate the UK's EU referendum and opportunities for similar processes in their own country. We can think of the degree of habitual voting, the quality of national political institutions (for example, levels of corruption), national endorsements of the $\mathrm{EU}$, and the degree to which the $\mathrm{EU}$ is a polarising issue in national politics (Hobolt 2012; Rose and Borz 2013; Schuck and de Vreese 2015). Theories about benchmarking (De Vries 2017) and media and party cue-taking (Hooghe and Marks 2005) present us with explanations of how the national context can substantially impact the framing of EU issues, including EU referendum demand.

Although we do not test for a direct cause-effect relationship between Brexit and referendum demand in other EU Member States, the country differences we find suggest that we cannot easily assume that mechanisms observed in one country, such as the UK in the context of an actual referendum, can be translated to other countries directly. Our findings hint at unique and country-specific dynamics to be driving much of the discussion about hypothetical referendums in other EU countries. This has to be kept in mind when speculating about, for example, EU referendums proposed in the French Presidential election campaign by the Front National or Partij van de Vrijheid in the Dutch parliamentary election campaign. Investigating the cause-effect relationship between Brexit and referendum demand in other countries would have required longitudinal survey data on public opinion or an experiment set before and after the UK's EU referendum. The data we use in this study do not permit such analysis and we are not aware of other available data that does. De Vries (2017) 
offers a closer inspection of the issue of Brexit spill over effects and some experimental data, but states that, even with such data, the potential causal impact of Brexit on public attitudes across the EU cannot be strictly evaluated.

In the search for uniform drivers of referendum demand across the countries we find that trust in EU institutions and identity are the only predictors demonstrating some degree of consistency. Echoing Rose and Borz (2013) our results suggest that, in the specific context of demand for EU referendums, sentiments about the EU's institutions weigh more heavily than sentiments about national political institutions. This challenges, to some extent, the notion that citizens formulate decisions about important EU-related matters by using domestic political evaluations as proxies (see Anderson 1998). We find little support for the congruence hypothesis. Trust in national institutions impacts referendum demand only in some of the countries in our study, suggesting that its effect might be moderated by the particular country context.

An even stronger, although less consistent, predictor of EU referendum demand is identity. Echoing Kriesi et al. (2006) and Hooghe and Marks (2005), we find a complex relationship that suggests that we need to take into account the interactions of national and European identity, as opposed to working with a binary distinction. Given that evaluations of identity have been found to impact attitudes to EU integration (Hooghe and Marks 2004), our finding could indicate that citizens make use of identity as well as a proxy, thinking about EU referendums strategically in light of their attitudes towards integration. We find that in some countries citizens with an exclusively national identity support a referendum, possibly because it provides an opportunity to voice concerns about European integration and an opportunity to pull their country out of the EU. Yet in other countries, such as Spain, those possessing both an exclusive European identity and an exclusive national identity are similarly likely to favour a referendum. We speculate that this suggests that some citizens think quite strategically about the likely outcome of the referendum before formulating their position on whether they would like to have one. It seems, once again, that national context has to be considered as moderating the effect of identity on referendum demand. Further research is required to disentangle this relationship and its mechanisms.

On the issue of thinking strategically, it is interesting to note the relationship between referendum demand and how individuals say they would vote if such a referendum were held. One might think that those who are more eurosceptic would welcome the prospect of a referendum on their country's membership of the EU. Such a referendum would, presumably, be one possible path to them attaining their preference, namely their country's withdrawal from the EU. It is interesting that a percentage of eurosceptics across our survey, albeit a small one (9 per cent), despite stating that they would vote to leave the EU if a referendum were held, nevertheless do not demand one. The much more pronounced mirror image of this can be seen amongst those respondents who, despite stating that they would vote remain in the EU if a referendum were held, nevertheless demand one (33 per cent). Those individuals are willing to take on the risk of a referendum even though it opens up the possibility of defeat, however far-fetched that might seem (indeed, many commentators and politicians in the UK were confident at the outset of the referendum campaign). It seems that respondents are not instinctively and unthinkingly either moving from support for the $\mathrm{EU}$ and thus rejection of a referendum on membership 
(to be sure of preserving that membership), or moving from rejection of the EU and thus acceptance of a referendum on membership (to deliver their preference).

Indeed, in our models we find that there is a substantial relationship between referendum demand and people's vote intentions in a hypothetical referendum on their country's membership of the EU. When we take vote intentions into account as a factor the strength of the relationships with other indicators is somewhat reduced. However, most relationships remain robust, suggesting that overall demand for referendums on EU membership is partially - but not solely - driven by people's desire for their country to be inside or outside the EU.

We speculate that some sort of risk assessment is playing a role here. Given that referendums are generally seen as votes that settle issues, at least in the medium-term, one might want to be confident of obtaining their preferred result before welcoming such a vote. Voters who support the EU, and who are confident that their fellow citizens would vote to remain, may conceivably want a referendum to settle the issue for a period of time, thus lancing the boil of euroscepticism in their country. Voters who reject the EU, and who are not confident that they could persuade enough of their fellow citizens to vote that way, may conceivably not demand a referendum for the same reason: it might settle the issue and thus take their policy preference off the table for a period of time. This is an area that would be interesting for further research given the growing academic literature on voters' risk assessments and strategic calculations.

\section{Conclusion}

Our key finding - that we cannot generalise across countries when it comes to demand for referendums on EU membership - shows how important it is to take national context into consideration. Given the constraints in available datasets as well as resource and time constraints of the research project, this analysis includes only six EU member states. Hence, only country differences can be pointed out. Other research has considered country-level factors that might provide some explanation of cross-national variation (Hobolt 2012; Rose and Borz 2013; Schuck and de Vreese 2015). Our research focuses on the individual level as it is concerned with exploring the relationship between our dependent variable and individual attitudes. Our dataset did not include country-level measures and with only six countries it made little sense to include country-level predictors. A systematic analysis of contextual factors requires a multi-level analysis of all EU member states that includes country-specific characteristics and allows for controlling their effects on, for example, evaluations of identity and immigration issues.

Regardless of country differences, our results indicate that we can assume demand for EU referendums and EU attitudes to be related at the individual level to some extent. Future research might investigate the two factors together in more detail and explore their relationship: Do EU attitudes actually drive referendum demand? Does referendum demand impact EU attitudes? While the data collected for this research did not allow for it, future analyses should focus on the relationship between EU referendum demand and attitudes towards the EU, and the path that citizens take when they form opinions on EU issues. Such an approach would require treating both EU referendum demand and likely voting behaviour in such a referendum simultaneously as dependent and independent variables and modelling them together. Structural equation models, which would include 
both of these factors as latent variables, would allow for the exploration of the association between them and other factors. Testing the two variables for endogeneity would further shed light on the particular relationship between them.

In order to answer some of the questions triggered by our research, such a model should also include factors that specifically help explain how dissatisfaction with the EU and evaluations of identity drive referendum demand. In this article, we have shown that it is not so much general political disaffection, but specific dissatisfaction with the performance of the EU that impacts whether or not citizens demand EU referendums. We need to understand what it is exactly that citizens are dissatisfied with. Especially when it comes to answering open questions on the relationship between identity and EU referendum demand, we need to understand the mechanism of the relationship between group membership, allegiances, and demand for referendums. Including measures of political efficacy and attitudes towards direct democracy in the analysis could help shed light on this relationship. Although, at the time of writing this article, it appeared that political forces calling for referendums on EU membership were in retreat, multiple crises continue to pose challenges to the EU and the overall political landscape remains uncertain. Our research offers some concrete findings that speak to the existing literature on public attitudes to European integration, whilst also posing new questions that seem likely to remain salient in the years ahead.

\section{Notes}

1.

The first being the UK's 1975 referendum and the second the UK's 2016 referendum.

2.

The survey was commissioned to be carried out by Millward Brown in close cooperation with the research team using the panel provided by Survey Sampling International (SSI) in all six countries.

3

Weights were created by means of simultaneous iterative proportional fitting.

4.

A methods note detailing this can be found here: https://www.research.aqmen.ac.uk/wpcontent/uploads/sites/27/2017/07/TheViewFromTheContinent_Methods-Note.pdf.

5 .

Question wording: 'Now thinking of [COUNTRY OF RESPONDENT], what do you think about holding a similar type of referendum as in Britain in which people would be asked whether they wanted [COUNTRY OF RESPONDENT] to remain part of the EU or to leave the EU?'

1: 'I would like [COUNTRY OF RESPONDENT] to hold a referendum on [COUNTRY OF RESPONDENT]'s EU membership'

2: 'I would not like [COUNTRY OF RESPONDENT] to hold a referendum on [COUNTRY OF RESPONDENT]'s EU membership'

3 'Don't know'.

6.

a. When a citizen from Belgium crosses the border to the Netherlands, they usually have to show their passport to a border officer.

b. Britain receives a discount on its membership payments to the European Union.

c. If someone from Finland moves to Britain and works there, they have to wait six months before they can receive the same level of state support British workers get.

d. When a citizen from Italy arrives by plane in Britain, they usually do not have to show their passport to a border officer.

e. All citizens of any EU country are free to move to any other EU country to live even if 
they do not want to take up work there.

f. Citizens of one EU member state who move to another EU country are allowed to vote in

European

Parliament elections in the new country.

\section{Disclosure statement}

No potential conflict of interest was reported by the authors.

\section{Funding}

This research was funded by the Economic and Social Research Council under its UK in a Changing Europe programme and the project was hosted by the Applied Quantitative Methods Network (AQMeN).

\section{References}

Anderson, C. 1998. "When in Doubt, Use Proxies: Attitudes toward Domestic Politics and Support for European Integration." Comparative Political Studies 31 (5): 569-601. doi:10.1177/00104140980 31005002.

Bagehot. 2016. "The Meaning of Brexit: An Interview with lan Bremmer." The Economist, Accessed 19 June 2017. http://www.economist.com/blogs/bagehot/2016/02/meaning-brexit

Boomgaarden, H., A. Schuck, M. Elenbaas, and C. De Vreese. 2011. "Mapping EU Attitudes: Conceptual and Empirical Dimensions of Euroscepticism and EU Support." European Union Politics 12 (2): 241-266. doi:10.1177/1465116510395411.

Bowler, S., and T. Donovan. 1998. Demanding Choices: Opinion, Voting, and Direct Democracy. Ann Arbor, Ml: University of Michigan Press.

Brack, N., and N. Startin. 2015. "Introduction: Euroscepticism, from the Margins to the Mainstream." International Political Science Review 36 (3): 239-249. doi:10.1177/0192512115577231.

Carey, S. 2002. "Undivided Loyalties: Is National Identity an Obstacle to European Integration?" European Union Politics 3 (4): 387-413. doi:10.1177/1465116502003004001.

Citrin, J., and J. Sides. 2004. "Can Europe Exist without Europeans? Problems of Identity in a Multinational Community." In Advances in Political Psychology, edited by M. Hermann, 41-69. Oxford: Elsevier.

Dalton, R. 1984. "Cognitive Mobilization and Partisan De-alignment in Advanced Industrial Democracies." Journal of Politics 46 (1): 264-284. doi:10.2307/2130444.

Dalton, R. J., W. P. Burklin, and A. Drummond. 2001. "Public Opinion and Direct Democracy." Journal of Democracy 12 (4): 141-153. doi:10.1353/jod.2001.0066.

De Vreese, C., and H. Boomgaarden. 2005. "Projecting EU Referendums: Fear of Immigration and Support for European Integration." European Union Politics 6 (1): 59-82. doi:10.1177/ 1465116505049608.

De Vries, C. 2017. "Benchmarking Brexit: How the British Decision to Leave Shapes EU Public Opinion." Journal of Common Market Studies 55: 38-53. early view doi:10.1111/jcms.12579.

De Vries, C., and E. Edwards. 2009. "Taking Europe to Its Extremes: Extremist Parties and Public Euroscepticism." Party Politics 15 (1): 5-28. doi:10.1177/1354068808097889.

De Vries, C., and M. Steenbergen. 2013. "Variable Opinions: The Predictability of Support for Unification in Mass European Publics." Journal of Political Marketing 12 (1): 121-141. doi:10.1080/15377857.2013.752654.

Diez Medrano, J. 2003. Framing Europe: Attitudes to European Integration in Germany, Spain and the United Kingdom. Princeton, NJ: Princeton University Press.

Diez Medrano, J., and P. Gutiérrez. 2001. "Nested Identities: National and European Identity in Spain." Ethnic and Racial Studies 24 (5): 753-778. doi:10.1080/01419870120063963. 
Donovan, T., and J. Karp. 2006. "Popular Support for Direct Democracy." Party Politics 12 (5): 668671. doi:10.1177/1354068806066793.

Emanuele, V., N. Maggini, and B. Marino. 2016. "Gaining Votes in Europe against Europe? How National Contexts Shaped the Results of Eurosceptic Parties in the 2014 European Parliament Elections." Journal of Contemporary European Research 12 (3): 697-715.

Henley, J. 2016. "Would Brexit Trigger a Domino Effect in Europe?" The Guardian, Accessed June 10. https://www.theguardian.com/world/2016/jun/10/brexit-domino-effect-europe-eu-referendum-uk

Hobolt, S. 2009. Europe in Question: Referendums on European Integration. Oxford: Oxford University Press.

Hobolt, S. 2012. "Public Opinion and Integration." In The Oxford Handbook of the European Union, edited by E. Jones, A. Menon, and S. Weatherill. Oxford: Oxford University Press (716-734).

Hobolt, S., and S. Brouard. 2011. "Contesting the European Union? Why the Dutch and French Rejected the European Constitution." Political Research Quarterly 64 (2): 309-322. doi:10.1177/ 1065912909355713.

Hobolt, S., and C. De Vries. 2016. "Public Support for European Integration." Annual Review of Political Science 19: 413-432. doi:10.1146/annurev-polisci-042214-044157.

Hooghe, L., and G. Marks. 2004. "Does Identity or Economic Rationality Drive Public Opinion on European Integration?" Political Science and Politics 37 (3): 415-420.

Hooghe, L., and G. Marks. 2005. "Calculation, Community, and Cues: Public Opinion on European Integration." European Union Politics 6 (4): 419-443. doi:10.1177/1465116505057816.

Inglehart, R. 1970. "Cognitive Mobilisation and European Identity." Comparative Politics 3 (1): 45-70. doi:10.2307/421501.

Kriesi, H., E. Grande, R. Lachat, M. Dolezal, S. Bornschier, and T. Frey. 2006. "Globalization and the Transformation of the National Political Space: Six European Countries Compared." European Journal of Political Research 45 (6): 921-956. doi:10.1111/j.1475-6765.2006.00644.x.

Kritzinger, S. 2003. "The Influence of the Nation-state on Individual Support for the European Union." European Union Politics 4 (2): 219-241. doi:10.1177/1465116503004002004.

Leconte, C. 2015. "From Pathology to Mainstream Phenomenon: Reviewing the Euroscepticism Debate in Research and Theory." International Political Science Review 36 (3): 250-263. doi:10.1177/0192512115576236.

Loveless, M. 2010. "Agreeing in Principle: Utilitarianism and Economic Values as Support for the European Union in Central and Eastern Europe." Journal of Common Market Studies 48 (4): 1083-1106. doi:10.1111/j.1468-5965.2010.02088.x.

McLaren, L. 2004. "Opposition to European Integration and Fear of Loss of National Identity: Debunking a Basic Assumption regarding Hostility to the Integration Project." European Journal of Political Research 43 (6): 895-912. doi:10.1111/j.0304-4130.2004.00179.x.

McLaren, L. 2007. "Explaining Mass-level Euroscepticism: Identity, Interests, and Institutional Distrust." Acta Politica 42 (2-3): 233-251. doi:10.1057/palgrave.ap.5500191.

Oliver, C. 2016. "Brexit Vote Set to Fuel More Referendums." Financial Times, May 9.

Rohrschneider, R. 2002. "The Democratic Deficit and Support of an EU-wide Government." American Journal of Political Science 46 (2): 463-475. doi:10.2307/3088389.

Rohrschneider, R., and S. Whitefield. 2006. "Political Parties, Public Opinion and European Integration in Post-communist Countries: The State of the Art." European Union Politics 7 (1): 141-160. doi:10.1177/1465116506060915.

Rose, R., and G. Borz. 2013. "What Determines Demand for European Union Referendums?" Journal of European Integration 35 (5): 619-633. doi:10.1080/07036337.2013.799938.

Sanchez-Cuenca, I. 2000. "The Political Basis of Support for European Integration." European Union Politics 1 (2): 147-171. doi:10.1177/1465116500001002001.

Schuck, A., and C. de Vreese. 2015. "Public Support for Referendums in Europe: A Cross-national Comparison in 21 Countries." Electoral Studies 38 (1): 149-158. doi:10.1016/j.electstud.2 015.02.012.

Stöckel, F. 2013. "Ambivalent or Indifferent? Reconsidering the Structure of EU Public Opinion." European Union Politics 13 (4): 23-45. doi:10.1177/1465116512460736. 
van Egmond, M., W. V. D. Brug, S. Hobolt, M. Franklin, and E. V. Sapir 2013. European Parliament

Election Study 2009, Voter Study. GESIS Data Archive, Cologne. ZA5055 Data file Version 1.1.0. 